\title{
COMPARISON OF REAL ESTATE MANAGEMENT SYSTEM IN CHINA AND POLAND
}

\author{
Marta Gross \\ Faculty of Geodesy, Geospatial and Civil Engineering \\ University of Warmia and Mazury in Olsztyn \\ e-mail:marta.gross@uwm.edu.pl
}

\author{
Chao Lin \\ School of Public Management \\ Shanxi University of Finance $\mathcal{E}$ Economics \\ e-mail:andrewlc@sina.cn
}

\begin{abstract}
Real estate management systems differ all over the world. Differences arise from the different history of regions, different cultures and customs. The paper presents information about the real estate management systems in China and Poland, two extremely different countries. The authors have tried to show the differences and similarities between the countries. The research methods that were used to prepare the paper include a TOWS/SWOT analysis and a comparative analysis.
\end{abstract}

Key words: management, real estate, TOWS/SWOT analysis, comparative analysis.

JEL Classification: $H 00, H 82, K 11, Q 15$.

Citation: Gross, M. \& Lin, C. (2020). Comparison of real estate management system in China and Poland. Real Estate Management and Valuation, 28(1), 13-27.

DOI: https:/ / doi.org/10.2478/remav-2020-0002

\section{Introduction}

Real estate management systems differ all over the world. Differences arise from the different history of regions, diverse cultures and customs. The paper presents information about the real estate management systems in China and Poland, two countries that are extremely different in just about every respect (the surface area of the country, culture, political system, amount of public real estate resources and their definition, and related legislation). The authors have tried to show differences and similarities between the two countries.

Real estate management, especially the management of public property, should be effective and based on clearly defined foundations, including a sound legislative framework that is easy to understand (simple management procedures), as emphasized by Godfrey (2007), Nowacki (2008), Kaganova et al. (2008), Kokot and Gnat (2010), Struzik and Źróbek (2010), Constantin et al. (2012), Požega et al. (2014), Gross and Źróbek (2015), Marona and van den Beemt-Tjeerdsma (2018) and others. Managers should be well qualified. Public real estate management should not differ from its private counterpart because they share the same purpose - maintaining real estate at least in the same state as on the day of signing a management agreement. Moreover, the owner's needs should be respected or statutory tasks should be implemented.

The aim of the paper is to emphasize the most important problems and to present information regarding real estate management in China and Poland. The paper also determines what management strategy is recommended for each country. The study was supported by a TOWS/SWOT analysis. 


\section{Data and Methods}

The research undertaken in the paper was divided into three main steps (Fig. 1). First, the real estate management systems in China and Poland were characterized. A literature review was carried out. Next, a comparative analysis of management in these two countries was undertaken. Some common features describing real estate management were chosen. The last part was a TOWS/SWOT analysis.

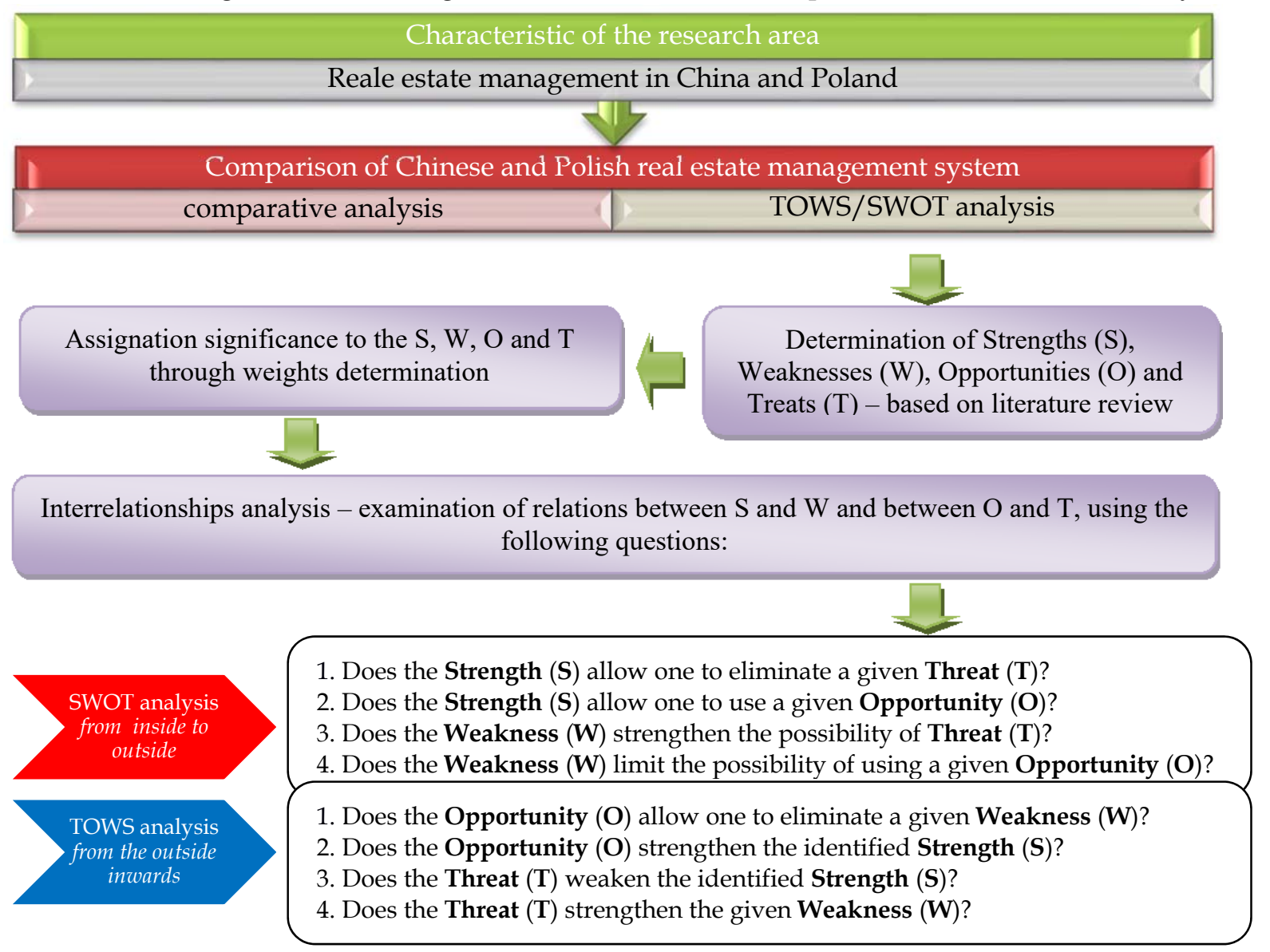

Fig. 1. The stages of the research and the methods used in the paper. Source: own study.

This type of analysis is very common. It has been used, for example, in cadastral and land administration systems (Bełej, 2001; Dawidowicz and Źrobek, 2011, 2014; Polat et al., 2017), to define directions of spatial development (Bieda and Brzozowska, 2017), to assess valuation methodology (Bieda et al., 2018), in the field of agricultural land protection (Pawlikowska et al., 2017) or for other purposes (Obłój, 2014).

Our TOWS/SWOT analysis was based on the preceding comparative analysis of the countries. The first step was to choose internal (strengths and weaknesses) and external (opportunities and threats) factors. The literature review and comparative analysis proved to be very helpful for this purpose. Then, weights were assigned to each factor in every group (strengths, weaknesses, opportunities and threats). The capacity of real estate management development was included. The weights were determined using the Delphi method - based on a survey conducted by 10 experts in the land management field. The respondents ranked the factors according to their significance (from the most to the least important) using the Tilgner scale (Bieda et al., 2018; Dawidowicz and Źrobek 2014 for Babbie 2008). It is a 5 point scale determining the impact of the factor on the real estate management system: 5 - maximal impact, 4 - significant, 3 - average, 2 - low, 1 - no impact. The weights were determined (based on results from the respondents' answers) using the following formula:

$$
W_{C_{i}}=\frac{p_{i}}{\Sigma p_{i}}
$$

where: $\mathrm{W}_{\mathrm{Ci}}$ - the weight of $i^{\text {th }}$ factor; $\mathrm{p}_{\mathrm{i}}$ - arithmetic mean of the points assigned by the respondents to the $i^{\text {th }}$ factor; $\sum p_{i}-$ sum of the points obtained in the same category. 
The next step of the research was to analyze the relationships between chosen factors (highest rated for each category), including 4 questions for SWOT analysis and 4 questions for TOWS analysis (provided in Figure 1). The assessment was based on a $0-1$ scale (0 - a relationship does not exist, 1 - a relationship exists).

The last step was to determine the strategy for real estate management in each country. We examined relationships as follows: SO (Strengths-Opportunities), ST (Strengths-Threats), WO (Weaknesses-Opportunities), WT (Weaknesses -Threats). According to OвŁóJ (2014) there are 4 possible strategies:

- aggressive (maxi-maxi) - is characterized by the dominance of strengths and opportunities created by the environment,

- conservative (maxi-mini) - minimizes threats appearing in the environment and maximizes strengths,

- competitive (mini-maxi) - minimizes weaknesses and maximizes opportunities,

- defensive (mini-mini) - minimizes weaknesses and threats appearing in the environment.

\section{Real estate management in China}

\subsection{Definition of real estate}

In China, the definition of real estate comprises land, ocean, housing, forest and other fixtures on land (Article 2, Real Estate Registration Ordinance, 2014). However, the notion of real estate in most situations refers to buildings attached to land. Thus, real estate management is divided into different administrative organizations. The Ministry of Housing and Urban-Rural Development is responsible for the whole process of housing development, while the Ministry of Natural Resources takes responsibility for natural resource management, including land, forest, grassland, etc. The paper will present the land and housing management in China.

\subsection{The land system in China}

China has a public land ownership system, including state land ownership and collective land ownership. Simply, the land belongs to the state in urban areas and is collective land elsewhere (Fig. 2). Under this framework of land ownership, two types of land tenure enjoy unequal rights. For the construction development of land, the granted land use right is that the land owner (the local government) grants a land tenure to land users for a limited period (e.g. residential land for 70 years, industrial land for 50 years) at the expense of land-transferring fees, which can be transferred, leased or mortgaged. A land use right for public benefit is granted free of charge. A land user must only submit an application to the city government and fulfil the land grant procedure, after which the allocated land can be transferred, leased or mortgaged. In line with the Land Management Law (2014) Article 43, all entities who need construction land apply for the use of state-owned land. Thus, the collective land use right is obviously limited, and applies to construction projects in towns or to building public facilities in rural areas. Land acquisition is the only channel for transformation from collective-owned to state-owned land (Fig. 2).

With respect to agricultural land management, the total area of state agricultural land is much smaller than collectively owned agricultural land, which is allocated to state-owned farms. Collective agricultural land consists of arable land, forests, gardens, mountains, prairies, mud flat, and so on. Since 1978, the household responsibility contract system has spread to all the rural areas in order to promote efficient agriculture. According to the Rural Land Contract Law (2019), every household is entitled to a rural land contract right, which can be transferred, mortgaged, or inherited. The contract time is a limited period, different for different land use types: 70 years for forest, 30 years for arable land, and 50 years for grassland.

\subsection{The housing system in China}

The housing system in China is divided into urban and rural segments (Fig. 3). In urban areas, all houses are built on state-owned land, including commercial and public housing. In the formerly planned economy, all urban citizens had to wait for the distribution of public housing built by the state. Since the reform in 1978 and subsequent open policy, the urban housing market has begun to explore new solutions supported by market mechanisms. In 1998, the State Council published the Note on the further reform of urban housing system and acceleration of housing construction (1998), which meant 
that the era of public housing was over. Urban dwellers are encouraged to improve their housing situation in the housing market instead of relying on welfare housing by the state. Most of public housing resources can be sold to private individuals at low prices in order to promote the reform of the urban housing system. Meanwhile, some public housing resources are left to local governments or military forces. The development of commercial housing is booming. Many people own private homes. Since 2008, affordable housing has been increasing in China in order to solve the housing problem of low-income people. In 2017, after the 19th National Congress of the Communist Party of China, the central government adjusted the focus of the housing reform, strengthening the development of the rental housing market in the future.

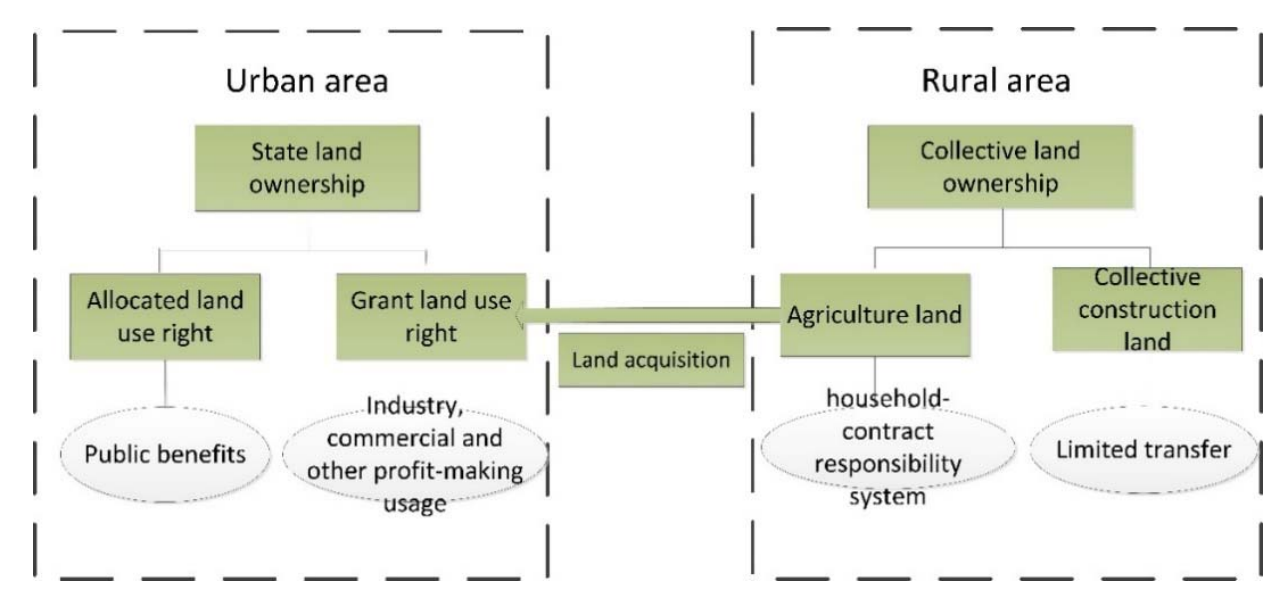

Fig. 2. The structure of property rights between state and collective construction land. Source: own study.

In rural areas, housing management depends on rural resident land (RRL). The system of RRL originated from the planned economy era. China collectivized all privately owned land into collective ownership, following the example of the Soviet Union. The collective authorities distributed plots of land to their members for housing purposes free of charge. Farmers built houses by themselves on rural residential land parcels. Thus, countryside residents enjoyed full ownership of housing, while the ownership of the land belonged to the collective authorities. Because of the welfare attribute of the RRL concept, RRL transfer is limited to members of the same collective and excludes urban citizens. Given the principle of integrating land and housing, private rural housing resources cannot be bought and sold. In reality, numerous urban dwellers have signed long-term rental contracts with owners of such properties to obtain an actual housing use right. Thus, the rural housing market is a closed, illiquid market when compared to the urban housing market.
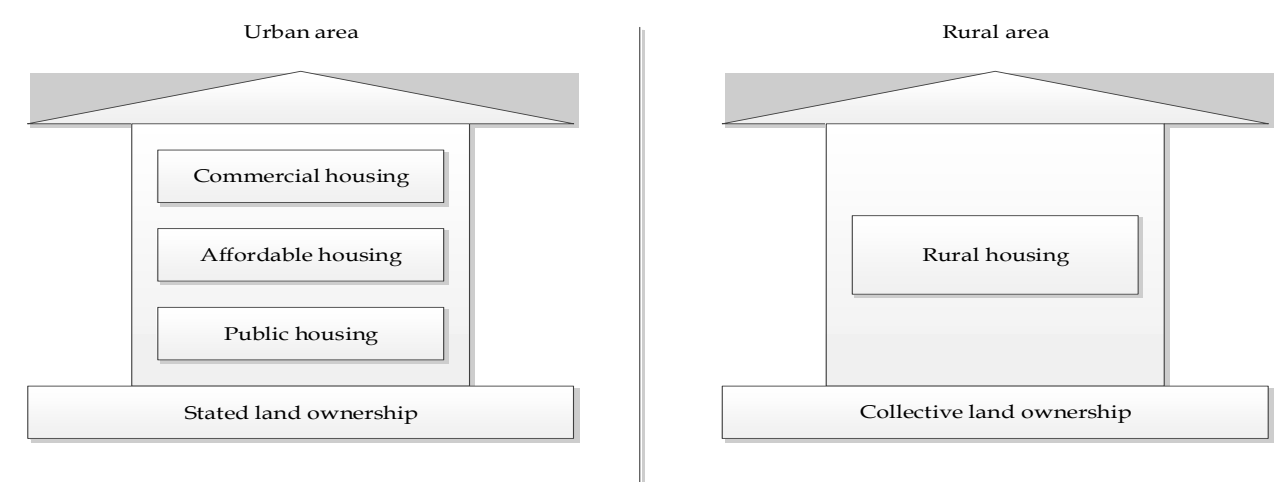

Fig. 3. Diagram of the urban-rural housing market. Source: own study.

\subsection{Real estate resources in China}

According to the Constitution of the PRC, all land, forest, water, grass, mountain, unused and other natural resource management belongs to all the people (stated) except for the provision regarding the collective part. Thus, the main part of real estate is public ownership, with the possibility of only the buildings being under private ownership (Fig. 4). Any entity can have land tenure with a limited duration except rural residential land. 


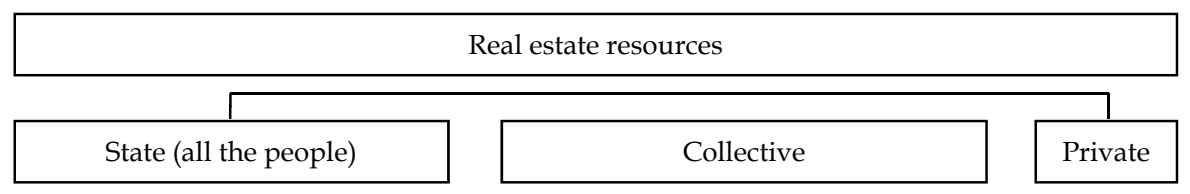

Fig. 4. Real estate resources of China. Source: own study.

All the real estate resources need to have different entities to take responsibility for their management (Fig. 5). The state ownership is entrusted to local government units, including provinces (23), national autonomous regions (5), municipalities (4, Beijing, Shanghai, Tianjin, Chongqing) and the Special Administrative Region (Hong Kong, Macao). Collective ownership consists of thousands of villages. The buildings belong to millions of private owners.

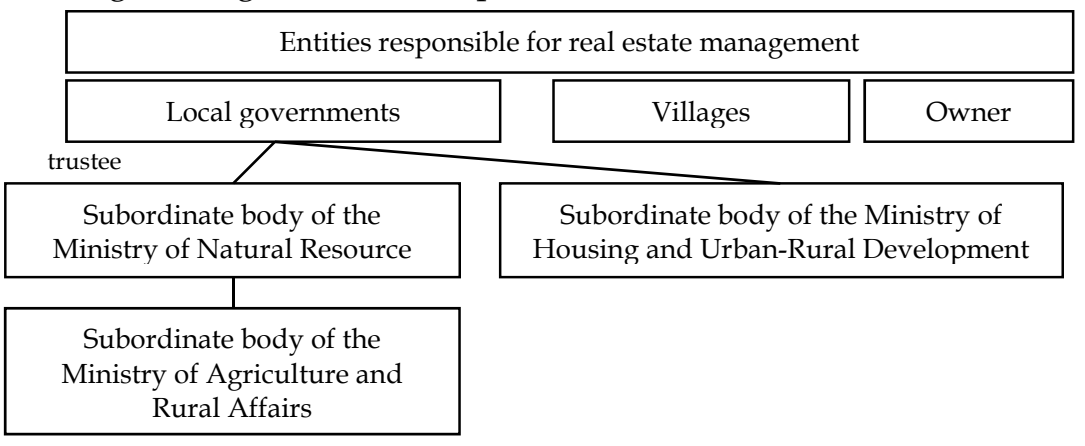

Fig. 5. Entities responsible for real estate management. Source: own study.

\subsection{Legal basis of real estate management in China}

In China, the legal system of real estate management consists of laws, regulations, measures and numerous administrative decisions. The Constitution of the PRC (2018) regulates some fundamental principles, and the Property Law (2007) and Land Management Law (2004) separately indicate the property right to all real estate resources and the basic land management system. As public land ownership is the core system in a socialist country, land management is a key part of a real estate system. Other real estate, including housing, nature parks, water bodies, etc., belongs to the land system. An obvious feature of land management in China is the segmentation of entities into a dual system: urban (state) and rural (collective), which was formed during the planned economy. Although dual land management has been undergoing gradual reformations since 1978, some reforms are not ideal and certain aspects still have not changed. Thus, there are a number of legal acts applied separately to urban or rural areas, and the two parts are not yet unified. Currently, some laws are outdated with respect to the actual situation, and therefore the authorities implement real estate management through many administrative decisions and other documents. Table 1 presents the most important legal acts concerning real estate management in China.

Table 1

The legal basis of real estate management in China

\begin{tabular}{|c|c|c|}
\hline Legal act & The scope of regulation & $\begin{array}{l}\text { Resource } \\
\text { which the } \\
\text { legal act } \\
\text { relates to }\end{array}$ \\
\hline $\begin{array}{l}\text { The Constitution of the People's } \\
\text { Republic of China ( } 2018 \text { amendment) }\end{array}$ & $\begin{array}{l}\text { The constitution regulates the basic system of real estate: } \\
\text { public land ownership and secures the legal private property } \\
\text { right of possession and inheritance. }\end{array}$ & $\begin{array}{c}\text { State, } \\
\text { collective, } \\
\text { private }\end{array}$ \\
\hline Property Law (2007) & $\begin{array}{l}\text { The act indicates the basic right of movable and immovable } \\
\text { property. }\end{array}$ & $\begin{array}{l}\text { State, } \\
\text { collective, } \\
\text { private }\end{array}$ \\
\hline $\begin{array}{l}\text { Land Management Law (2004 } \\
\text { amendment) }\end{array}$ & $\begin{array}{l}\text { The act indicates the management rules of land including } \\
\text { state, collective land. }\end{array}$ & $\begin{array}{c}\text { State, } \\
\text { collective }\end{array}$ \\
\hline Rural Land Contract Law & $\begin{array}{l}\text { The act indicates the rights and obligations of rural land } \\
\text { contract right and management rules. }\end{array}$ & Collective \\
\hline Forest Law (2009 amendment) & The act regulates the rules of forest management. & State, \\
\hline
\end{tabular}




\section{S sciendo}

\begin{tabular}{llc}
\hline & & collective \\
\hline Grassland Law (2013 amendment) & The act regulates the rules of grassland management. & $\begin{array}{c}\text { State, } \\
\text { collective }\end{array}$ \\
\hline $\begin{array}{l}\text { Law on Urban Real Estate } \\
\text { Management (2009 amendment) }\end{array}$ & $\begin{array}{l}\text { The act indicates the process of urban real estate, including } \\
\text { development, transaction, mortgage, rent, registration, } \\
\text { agency. }\end{array}$ & $\begin{array}{c}\text { State, } \\
\text { private }\end{array}$ \\
\hline $\begin{array}{l}\text { Real Estate Registration Ordinance } \\
\text { (2015) }\end{array}$ & $\begin{array}{l}\text { The ordinance indicates the procedure of land, sea, housing, } \\
\text { forest and other real estate registration and the registration } \\
\text { management system. }\end{array}$ & $\begin{array}{c}\text { State, } \\
\text { collective, } \\
\text { private }\end{array}$ \\
\hline $\begin{array}{l}\text { Regulations on Urban Real Estate } \\
\text { Development and Management }\end{array}$ & $\begin{array}{l}\text { The regulation specifies some details of management in } \\
\text { urban real estate development. }\end{array}$ & State \\
\hline $\begin{array}{l}\text { Measures for commercial housing } \\
\text { transaction management }\end{array}$ & $\begin{array}{l}\text { The act indicates the management of commercial housing } \\
\text { transactions and protection of the benefits of both parties. }\end{array}$ & Private \\
\hline $\begin{array}{l}\text { Note on the further improvement of } \\
\text { agricultural reclamation reform and } \\
\text { development }\end{array}$ & $\begin{array}{l}\text { The act indicates a further reform of state agricultural land } \\
\text { management. }\end{array}$ & State \\
$\begin{array}{l}\text { Opinions on expanding the scope of } \\
\text { paid use of state-owned land }\end{array}$ & $\begin{array}{l}\text { The act indicates that the scope of the state-owned land } \\
\text { should be extended in order to promote marketization. }\end{array}$ & State \\
\hline
\end{tabular}

Source: own study.

\section{Real estate management in Poland}

\subsection{Definition of real estate}

In Poland, real estate is the part of the earth's surface which is determined as separate ownership objects (land parcels), as well as buildings permanently attached to the ground or parts of such buildings if they are a separate object of ownership under the special regulations (Civil Code, 1964).

\subsection{The land system in Poland}

Poland is a country where private ownership prevails (Fig. 6). Public real estate also represent a significant percentage.

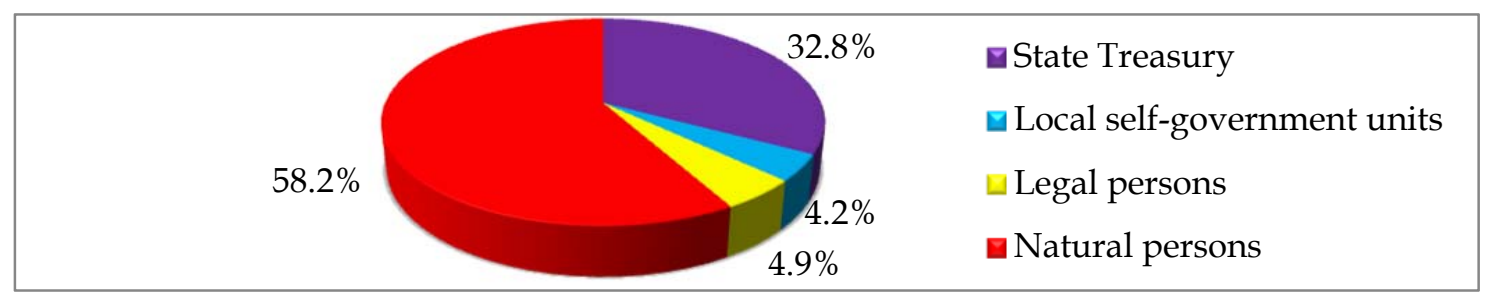

Fig. 6. Real estate in Poland. Source: own study based on THE GENERAL COUNSEL TO THE REPUBLIC OF POLAND (2018).

The owner of a real estate is responsible for its management. As a rule, there are no restrictions, besides obeying the principles of law and social coexistence. The owner is obliged to use the real estate in accordance with the socio-economic purpose of the given property (Civil Code, 1964). There exists a constitutional right of the ownership's protection. All rights to the real estate are registered. There is also a clear division of the responsibility at each level of the territorial division of the country in the scope of real estate management in the case of public properties.

Real estate can be sold, exchanged, relinquished, put into perpetual usufruct, leased, rented, let into permanent management, encumbered by limited property rights, etc. (Real Estate Management Act - REMA, 1997).

\subsection{The housing system in Poland}

The municipality's task is to meet the housing needs of its citizens (low income households). It provides premises within the framework of social rent and convertible premises (ACT OF THE PROTECTION OF TENANTS' RIGHTS, MUNICIPAL HOUSING STOCK AND THE AMENDMENT OF THE CIVIL CODE 2001). Citizens can apply for help - a housing benefit. This is a donation to pay for rent or real estate maintenance costs. People entitled to a housing benefit are, inter alia, the following: tenants and subtenants of housing premises, owners of self-contained housing premises, other people without a title to the housing premise but covering costs related to the occupied premise. 
Poland created Social Housing Associations (TBS), which is a form of support for people who cannot afford to buy their own premises aon the real estate market, but due to too high income, cannot obtain it from the municipality's resources. TBS builds dwellings and then leases the premises. The household should have appropriate income and the tenant cannot hold a title to another premise.

The government program - Mieszkanie Plus is, just like in the case of TBS, a proposal for those who cannot buy their own premise and whose income is too high to get a premise from the municipality.

\subsection{Real estate resources in Poland}

REMA (1997) distinguishes 4 public real estate resources: municipal, district, voivodeship (local government units' resources) and the State Treasury (Fig. 7). This corresponds to the territorial division of the country. There are 16 voivodeships, 380 districts (314 land districts and 66 cities with district status) and 2478 municipalities in Poland (GUS 2019). There is also a resource of private real estates.

According to REMA (1997), real estate resources (public, not private) consist of properties that are owned by a municipality, district, voivodeship or the State Treasury, and they have not been put into perpetual usufruct, as well as properties which are the subject of perpetual usufruct of a municipality, district, voivodeship or the State Treasury. Perpetual usufruct only concerns the right to land, which is in the ownership of a municipality, district, voivodship or the State Treasury. A perpetual usufructuary can use land in the same way as an owner. The only limitation is a provision in a perpetual usufruct agreement that sets a certain time to develop the land. The perpetual usufructuary becomes the owner of buildings erected of the land. The right is limited in time - the duration is usually 99 years, with a minimum of 40 years. It can be inherited and transferred into an ownership right.

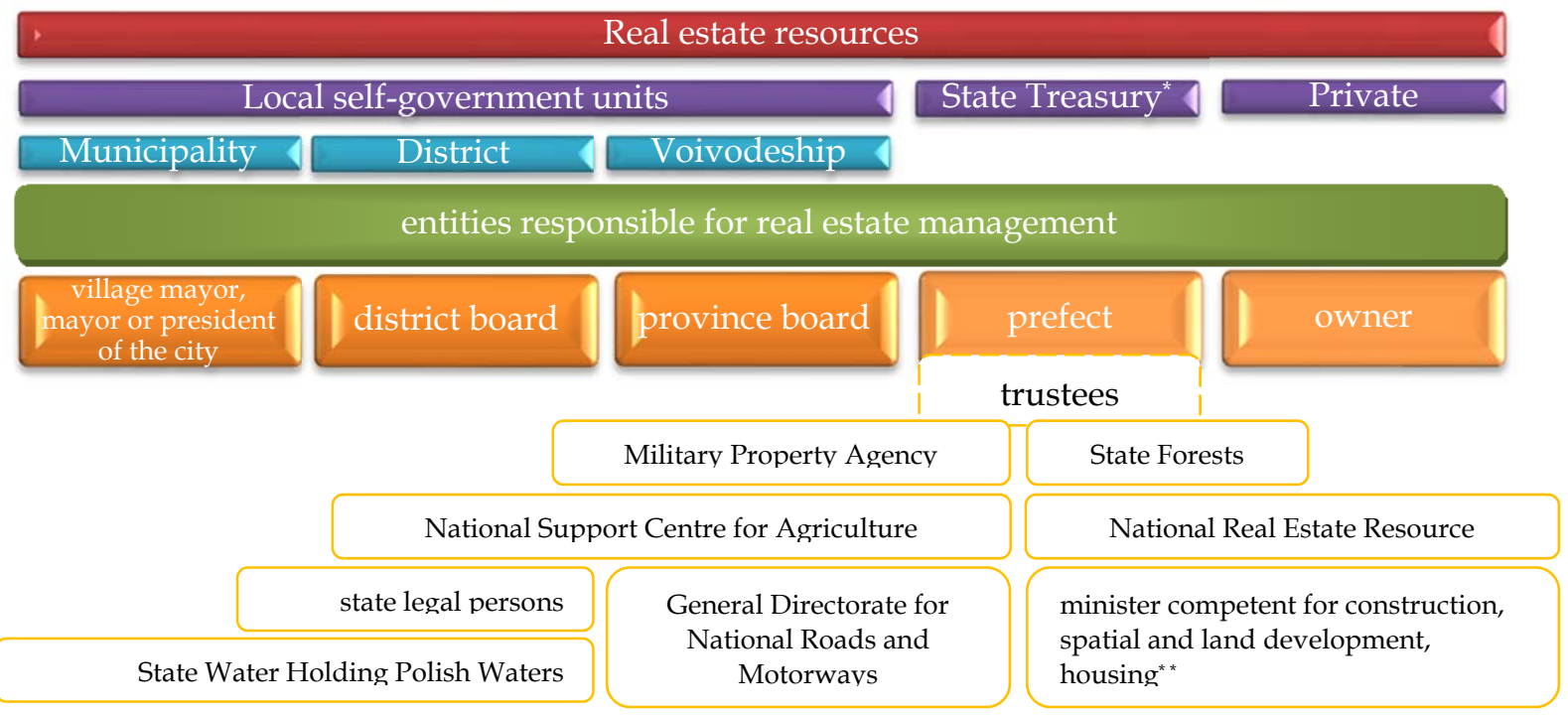

* in legal, financial and accounting meaning, ${ }^{* *}$ currently: Ministry of Investment and Economic Development

Fig. 7. Real estate resources in Poland and entities responsible for their management. Source: own study.

Figure 7 presents all of the real estate resources existing in the Polish system. Local selfgovernment units have their own bodies responsible for management. These area village mayor, a mayor or president of a town or city (in a municipality), district board (in a district) and province board (in a voivodship). Local government units can also create different organizational and legal forms, e.g. a company or public private partnership, to outsource some of their tasks. The general rule is that state properties are managed by the prefect (starosta) who is responsible for executing tasks in the scope of government administration. An exception is possible, namely, the mayor of a district town can be responsible for real estate management in some cases. Some properties from this resource are separated into different categories of assets. There are different trustees responsible for the State Treasury management: the Military Property Agency, State Forests, National Support Centre for Agriculture, National Real Estate Resource, General Directorate for National Roads and Motorways, 
State Water Holding Polish Waters, Ministry of Investment and Economic Development, and state legal persons.

\subsection{Legal basis of real estate management in Poland}

Table 2 presents the most important legal acts relating directly or indirectly to public real estate resources (as of 28 February 2019), together with a brief description of their content.

CIVIL CODE (1964) contains the most general, universal rules regarding real estate management (BIENIEK 2011), public as well as private. The rules of using a property by its owner are specified in this law. The so-called triad of the owner's rights - the right to use, collect benefits and dispose of real estate, are defined there. This law applies to all the properties in Poland. Detailed principles of public real estate management, due to their subjective affiliation, are specified in REMA (1997) and its executive acts.

There are also some other regulations, for example executive acts, which describe, in detail, such procedures as selling or leasing state properties.

Legal acts concerning real estate management in Poland

Table 2

\begin{tabular}{|c|c|c|}
\hline Legal act & The scope of regulation & $\begin{array}{l}\text { Resource, } \\
\text { which the legal } \\
\text { act relates to }\end{array}$ \\
\hline $\begin{array}{l}\text { The Constitution of the } \\
\text { Republic of Poland } \\
\text { (1997) }\end{array}$ & $\begin{array}{l}\text { The act indicates that the Republic of Poland secures the right of } \\
\text { possession and inheritance. The ownership right can be limited } \\
\text { only by law and only when such a limitation does not affect the } \\
\text { essence of this right. }\end{array}$ & Public, Private \\
\hline Civil Code (1964) & $\begin{array}{l}\text { The code includes inter alia regulations concerning ownership } \\
\text { right and other property rights. }\end{array}$ & Public, Private \\
\hline REMA (1997) & $\begin{array}{l}\text { The act determines, inter alia, the rules of public property } \\
\text { management. It describes the procedure and rules for selling and } \\
\text { letting public properties into perpetual usufruct or permanent } \\
\text { management. It also includes information about the amount due } \\
\text { and terms of the payment of prices and fees for public real estate. } \\
\text { The act also determines the procedure of land consolidation, } \\
\text { division, real estate valuation or expropriation. }\end{array}$ & Public, Private \\
\hline Forests Act (1991) & $\begin{array}{l}\text { The act regulates inter alia the rules of forest management, } \\
\text { regardless of the form of their ownership. }\end{array}$ & Public, Private \\
\hline $\begin{array}{l}\text { State-owned } \\
\text { Agricultural Real Estate } \\
\text { Management Act (1991) }\end{array}$ & $\begin{array}{l}\text { The act regulates the rules of managing the State Treasury } \\
\text { agricultural properties, other real estates which were left after the } \\
\text { liquidation of state agricultural farms and their unions and } \\
\text { associations, as well as forests which are not separated } \\
\text { geodetically from such properties. These rules also apply to } \\
\text { properties let into perpetual usufruct by natural persons. }\end{array}$ & Public, Private \\
\hline $\begin{array}{l}\text { Forming Agricultural } \\
\text { System Act (2003) }\end{array}$ & $\begin{array}{l}\text { The act gives information on how to improve the area structure of } \\
\text { farms, counteract excessive concentration of agricultural property, } \\
\text { and what qualifications farmer should have. }\end{array}$ & Public, Private \\
\hline $\begin{array}{l}\text { Act on National Support } \\
\text { Centre for Agriculture } \\
(2017)\end{array}$ & $\begin{array}{l}\text { The act determines the organization and tasks of the National } \\
\text { Support Centre for Agriculture }\end{array}$ & Public \\
\hline $\begin{array}{l}\text { Military Property } \\
\text { Agency Act (2015) }\end{array}$ & $\begin{array}{l}\text { The law determines, inter alia, the organization and tasks of the } \\
\text { Military Property Agency, as well as the principles and } \\
\text { procedures for state property management. }\end{array}$ & Public \\
\hline $\begin{array}{l}\text { Act on National Real } \\
\text { Estate Resource (2017) }\end{array}$ & $\begin{array}{l}\text { The act determines the principles of founding and operating the } \\
\text { National Real Estate Resource, as well as the rules of transferring } \\
\text { real estates to the National Real Estate Resource. }\end{array}$ & Public \\
\hline $\begin{array}{l}\text { Municipal Government } \\
\text { Act (1990) }\end{array}$ & $\begin{array}{l}\text { The act defines, inter alia, the tasks of a municipality, its bodies, } \\
\text { financial management and some principles concerning municipal } \\
\text { assets. }\end{array}$ & Public \\
\hline $\begin{array}{l}\text { District Government Act } \\
\text { (1998) }\end{array}$ & $\begin{array}{l}\text { The act defines, inter alia, the tasks of a district, its bodies, financial } \\
\text { management and some principles concerning the district's assets. }\end{array}$ & Public \\
\hline $\begin{array}{l}\text { Voivodeship } \\
\text { Government Act (1998) }\end{array}$ & $\begin{array}{l}\text { The act defines, inter alia, the tasks of a voivodship, its bodies, } \\
\text { financial management and some principles concerning the }\end{array}$ & Public \\
\hline
\end{tabular}


voivodeship's assets.

Public Finance Act (2009) $\quad$ It determines, inter alia, units of the public finance sector and the Public principles of managing public funds

Act on Acquisition of The act specifies the procedure of real estate acquisition by Public, Private

Properties by Foreigners foreigners.

(1920)

Act on Transformation

of Perpetual Usufruct

The act determines the principles and procedure of transformation

Public, Private

Right into the

of perpetual usufruct right into the ownership right.

Ownership Right (2005)

Act on Transformation

of Perpetual Usufruct

Right of Built-up Lands

for Residential Purposes

into the ownership Right

to this Lands (2018)

State Property

Management's Principles

Act (2016)

Council of Ministers'

decree on the manner

and procedure of

conducting tenders and

negotiations for real

estate sale (2004)

Council of Ministers'

decree on real estate land

consolidation (2005)

Council of Ministers'

decree on the manner

and procedure of

performing real estate

division (2004)

The act informs that, on 1.01.2019, the perpetual usufruct right of

Public, Private

land developed for housing purposes is transformed into the

ownership right of this land. It also determines the rules of the

transformation.

The act contains the rules concerning state real estate management
(these which were not included in special regulations).

The decree specifies the manner and procedure of conducting

Public

tenders when real estate belonging to a local self-government unit

or the State Treasury is being sold. It also determines the

procedure of selling real estate in negotiations when two

subsequent tenders ended with a negative result.

The decree specifies the manner and procedure of land

Public, Private

consolidation and the way in which an adjacent fee is determined.

The decree specifies the manner and procedure of real estate division.

Public, Private

Source: own study

\section{Empirical results}

The authors chose 12 features to make a comparative analysis of real estate management in China and Poland. Table 3 presents the similarities and differences observed in the process.

Table 3

Comparison of property management in China and Poland

\begin{tabular}{lll}
\hline \multicolumn{1}{c}{ Feature } & \multicolumn{1}{c}{ China } & \multicolumn{1}{c}{ Feature's description } \\
\cline { 2 - 3 } Legal systems & $\begin{array}{l}\text { Lack of unified Real Estate Law, all types } \\
\text { of real estate management are governed by } \\
\text { separate laws }\end{array}$ & $\begin{array}{l}\text { Detailed legislative framework. Civil Code } \\
(1964) \text { is unified for all types of real estate. } \\
\text { There are also separate laws for some kinds } \\
\text { of real estate, for example for public ones. }\end{array}$ \\
\hline $\begin{array}{l}\text { Property right } \\
\text { protection and } \\
\text { equality }\end{array}$ & $\begin{array}{l}\text { State and collective land are not equal in } \\
\text { the real estate market. The disposition right } \\
\text { of collective land is relatively weaker. The } \\
\text { right of ownership of a private house is } \\
\text { secured by law, except land acquisition. }\end{array}$ & $\begin{array}{l}\text { Right of possession and inheritance are } \\
\text { secured by law. }\end{array}$ \\
\hline $\begin{array}{l}\text { Unified real estate } \\
\text { registration and } \\
\text { information system }\end{array}$ & $\begin{array}{l}\text { Not implemented yet, the reform is } \\
\text { underway. }\end{array}$ & $\begin{array}{l}\text { The second phase of creating the Integrated } \\
\text { Real Estate Information System (ZSIN) has } \\
\text { finished. }\end{array}$ \\
\hline Effectiveness & $\begin{array}{l}\text { High effectiveness for public facility } \\
\text { construction such as a High Speed } \\
\text { Railway, a highway, etc. }\end{array}$ & $\begin{array}{l}\text { low effectiveness of public resources - } \\
\text { progressive debt of local self-government } \\
\text { units; there is a belief that public means } \\
\text { less effective; sometimes public is treated } \\
\text { as nobody's assets (common good belongs }\end{array}$ \\
\hline
\end{tabular}




\begin{tabular}{|c|c|c|}
\hline & & to the society) \\
\hline $\begin{array}{l}\text { Government } \\
\text { having the capacity } \\
\text { to control public } \\
\text { real estate of }\end{array}$ & Strong & Strong \\
\hline $\begin{array}{l}\text { Market mechanism } \\
\text { of real estate } \\
\text { transaction }\end{array}$ & $\begin{array}{l}\text { The role that the market mechanism plays } \\
\text { is not sufficient, and numerous obstacles } \\
\text { need be reformed. Administrative } \\
\text { intervention in the real estate market is } \\
\text { strong. }\end{array}$ & $\begin{array}{l}\text { There is no administrative intervention in } \\
\text { the real estate market. The exception is } \\
\text { expropriation for public purposes and pre- } \\
\text { emption right. }\end{array}$ \\
\hline $\begin{array}{l}\text { The reform of land } \\
\text { expropriation }\end{array}$ & $\begin{array}{l}\text { The reform aims to narrow the scope of } \\
\text { public benefit, increasing multiple kinds of } \\
\text { compensation }\end{array}$ & $\begin{array}{l}\text { Compensation for expropriated property } \\
\text { corresponds to the market value. It does } \\
\text { not include losses resulting from the loss of } \\
\text { rights to real estate. According to WALACIK } \\
\text { (2014), the list of components considered } \\
\text { for estimating just compensation should be } \\
\text { broadened. }\end{array}$ \\
\hline $\begin{array}{l}\text { Increase of market } \\
\text { normalization }\end{array}$ & $\begin{array}{l}\text { The reform aims to supply more } \\
\text { transparency, fewer procedures of } \\
\text { management. }\end{array}$ & $\begin{array}{l}\text { There is no need to increase market } \\
\text { normalization. Some management } \\
\text { procedures are complicated and detailed. }\end{array}$ \\
\hline $\begin{array}{l}\text { Growing debt of } \\
\text { governments }\end{array}$ & $\begin{array}{l}\text { A big crisis in China, prompting the central } \\
\text { government to implement many solutions } \\
\text { in order to decrease the debt of local } \\
\text { governments }\end{array}$ & $\begin{array}{l}\text { Lack of financial resources for the } \\
\text { implementation of public purpose } \\
\text { developments, and growing debt of local } \\
\text { self-government units. }\end{array}$ \\
\hline $\begin{array}{l}\text { Environment } \\
\text { protection }\end{array}$ & $\begin{array}{l}\text { Stronger than in the past, affecting land } \\
\text { management }\end{array}$ & $\begin{array}{l}\text { It should be included in real estate } \\
\text { management procedures. }\end{array}$ \\
\hline $\begin{array}{l}\text { Macroeconomic } \\
\text { environment }\end{array}$ & $\begin{array}{l}\text { Economic growth has slowed down to } \\
\text { medium-high speed. }\end{array}$ & $\begin{array}{l}\text { Polish economy is stable. GDP has been } \\
\text { growing. }\end{array}$ \\
\hline $\begin{array}{l}\text { Public private } \\
\text { partnership (PPP) }\end{array}$ & There is a large use of PPP projects & $\begin{array}{l}\text { More and more PPP projects are used to } \\
\text { achieve public purposes }\end{array}$ \\
\hline
\end{tabular}

Source: own study.

Next, a TOWS/SWOT analysis was carried out. Tables 4 and 5 present internal (strengths and weaknesses) and external (opportunities and threats) factors and their weights. Table 6 and 7 present relationships between the factors.

Table 4

Internal and external factors of analysis concerning property management in China

\begin{tabular}{|c|c|c|c|c|}
\hline \multirow{7}{*}{ 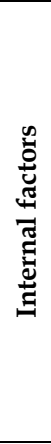 } & Strengths (S) & Weight & Weakness (W) & Weight \\
\hline & S1 - Effectiveness & 0.4 & $\begin{array}{l}\text { W1 - Administrative intervention in the } \\
\text { real estate market }\end{array}$ & 0.3 \\
\hline & S2 - Legal system & 0.2 & W2 - Lack of legal transparency & 0.3 \\
\hline & $\begin{array}{l}\text { S3 - Property right protection and } \\
\text { equality }\end{array}$ & 0.2 & $\begin{array}{l}\text { W3 - Market mechanism of real estate } \\
\text { transaction. }\end{array}$ & 0.2 \\
\hline & $\begin{array}{l}\text { S4 - Control ability of public real } \\
\text { estate of governments }\end{array}$ & 0.1 & $\begin{array}{l}\text { W4 - Lack of an integrated registration } \\
\text { and information system concerning real } \\
\text { estate }\end{array}$ & 0.1 \\
\hline & S5 - A large number of PPP projects & 0.1 & W5 - Compensation of land expropriation & 0.1 \\
\hline & Sum of weights & 1.0 & Sum of weights & 1.0 \\
\hline \multirow{5}{*}{ 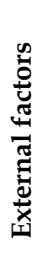 } & Opportunities (O) & Weight & Threats (T) & Weight \\
\hline & O1 - Increase of market normalization & 0.5 & T1 - Growing debts of governments & 0.5 \\
\hline & O2 - The reform of land expropriation & 0.3 & T2 - Macroeconomic environment & 0.3 \\
\hline & $\begin{array}{l}\text { O3 - Creation of an integrated } \\
\text { information system concerning real } \\
\text { estate }\end{array}$ & 0.2 & T3 - Environment protection & 0.2 \\
\hline & Sum of weights & 1.0 & Sum of weights & 1.0 \\
\hline
\end{tabular}

Source: own study. 
Table 5

Internal and external factors of analysis concerning property management in Poland

\begin{tabular}{|c|c|c|c|c|}
\hline \multirow{6}{*}{ 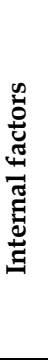 } & Strengths (S) & Weight & Weakness (W) & Weight \\
\hline & S1 - Legal system & 0.3 & W1 - Effectiveness & 0.4 \\
\hline & $\begin{array}{l}\text { S2 - Property right protection and } \\
\text { equality }\end{array}$ & 0.3 & W2 - Lack of legal transparency & 0.3 \\
\hline & $\begin{array}{l}\text { S3 - Existence of the Integrated Real } \\
\text { Estate Information System (ZSIN) }\end{array}$ & 0.3 & $\begin{array}{l}\text { W3 - Some management procedures are } \\
\text { complicated and detailed. }\end{array}$ & 0.2 \\
\hline & $\begin{array}{l}\text { S4 - Market mechanism of real estate } \\
\text { transaction. }\end{array}$ & 0.1 & $\begin{array}{l}\text { W4 - Compensation of land } \\
\text { expropriation }\end{array}$ & 0.1 \\
\hline & Sum of weights & 1.0 & Sum of weights & 1.0 \\
\hline \multirow{5}{*}{ 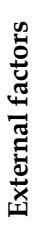 } & Opportunities (O) & Weight & Threats (T) & Weight \\
\hline & O1 - Completion of works on the ZSIN & 0.5 & T1 - Growing debts of governments & 0.5 \\
\hline & O2 - More PPP projects & 0.3 & $\begin{array}{l}\text { T2 - Legal limitations of sharing data } \\
\text { form ZSIN }\end{array}$ & 0.3 \\
\hline & O3 - The reform of land expropriation & 0.2 & T3 - Environment protection & 0.2 \\
\hline & Sum of weights & 1.0 & Sum of weights & 1.0 \\
\hline
\end{tabular}

Source: own study.

Table 6

SWOT and TOWS analysis of interrelationships concerning property management in China

\begin{tabular}{ccccccc}
\hline SWOT & O1 & O2 & O3 & T1 & T2 & T3 \\
\hline S1 & 0 & 0 & 1 & 0 & 0 & 1 \\
\hline S2 & 1 & 1 & 1 & 0 & 1 & 1 \\
\hline S3 & 0 & 0 & 0 & 0 & 1 & 0 \\
\hline S4 & 0 & 0 & 1 & 1 & 1 & 1 \\
\hline S5 & 0 & 0 & 0 & 1 & 1 & 0 \\
\hline W1 & 1 & 1 & 1 & 1 & 1 & 1 \\
\hline W2 & 1 & 1 & 1 & 1 & 1 & 1 \\
\hline W3 & 1 & 1 & 0 & 1 & 1 & 0 \\
\hline W4 & 1 & 0 & 1 & 0 & 0 & 0 \\
\hline W5 & 0 & 1 & 0 & 0 & 1 & 0 \\
\hline
\end{tabular}

\begin{tabular}{ccccccccccr}
\hline TOWS & S1 & S2 & S3 & S4 & S5 & W1 & W2 & W3 & W4 & W5 \\
\hline O1 & 1 & 1 & 0 & 0 & 1 & 1 & 1 & 1 & 0 & 1 \\
\hline O2 & 1 & 1 & 1 & 0 & 0 & 0 & 1 & 1 & 0 & 1 \\
\hline O3 & 0 & 0 & 1 & 0 & 0 & 0 & 1 & 0 & 1 & 0 \\
\hline $\mathrm{T} 1$ & 1 & 0 & 0 & 1 & 0 & 1 & 1 & 1 & 0 & 0 \\
\hline $\mathrm{T} 2$ & 0 & 0 & 0 & 0 & 1 & 0 & 0 & 0 & 0 & 1 \\
\hline $\mathrm{T} 3$ & 0 & 0 & 0 & 0 & 1 & 0 & 0 & 0 & 0 & 0 \\
\hline
\end{tabular}

Source: own study

Table 7

SWOT and TOWS analysis of interrelationships concerning property management in Poland

\begin{tabular}{ccccccc}
\hline SWOT & O1 & O2 & O3 & T1 & T2 & T3 \\
\hline S1 & 1 & 1 & 1 & 0 & 1 & 1 \\
\hline S2 & 0 & 0 & 0 & 0 & 0 & 1 \\
\hline S3 & 1 & 0 & 1 & 0 & 1 & 0 \\
\hline S4 & 0 & 1 & 0 & 1 & 1 & 1 \\
\hline $\mathrm{W} 1$ & 1 & 1 & 1 & 1 & 1 & 1 \\
\hline $\mathrm{W} 2$ & 1 & 1 & 1 & 1 & 1 & 1 \\
\hline $\mathrm{W} 3$ & 0 & 1 & 0 & 0 & 0 & 0 \\
\hline $\mathrm{W} 4$ & 0 & 0 & 0 & 0 & 0 & 0 \\
\hline
\end{tabular}

\begin{tabular}{ccccccccc}
\hline TOWS & S1 & S2 & S3 & S4 & W1 & W2 & W3 & W4 \\
\hline O1 & 0 & 1 & 1 & 0 & 0 & 0 & 0 & 0 \\
\hline O2 & 0 & 0 & 0 & 0 & 0 & 0 & 1 & 0 \\
\hline O3 & 1 & 1 & 0 & 0 & 0 & 0 & 0 & 0 \\
\hline $\mathrm{T} 1$ & 0 & 0 & 1 & 1 & 1 & 0 & 0 & 0 \\
\hline $\mathrm{T} 2$ & 1 & 0 & 0 & 1 & 0 & 0 & 0 & 0 \\
\hline $\mathrm{T} 3$ & 0 & 0 & 0 & 1 & 0 & 0 & 0 & 0 \\
\hline
\end{tabular}

Source: own study.

Next, the strategy for real estate management in each country was determined (Table 8, Fig. 8).

The table contains a number of interactions and the weighted interactions for factors from Table 6 and 7. These two values were determined in the TOWS, SWOT and TOWS/SWOT analysis. The examined relationships were as follows: SO (Strengths-Opportunities), ST (Strengths-Threats), WO (Weaknesses-Opportunities), WT (Weaknesses -Threats). Based on Table 8 and Figure 8, a two-way comparison of real estate management factors was made: from the outside to the inside, and from the inside to the outside (TOWS/SWOT analysis). We determined the strategies for each country. China 


\section{S sciendo}

obtained the highest score for competitive strategy (WO), marked in blue colour in Table 8 and Figure 8. Poland presents a conservative strategy (ST), marked in dark green colour.

Table 8

A summary of TOWS/SWOT analysis - case study of China and Poland

\begin{tabular}{|c|c|c|c|c|c|}
\hline & \multicolumn{2}{|c|}{ CHINA } & \multicolumn{3}{|c|}{ POLAND } \\
\hline & Opportunities & Threats & Opportunities & Threats & \\
\hline & Aggressive strategy & Conservative strategy & Aggressive strategy & Conservative strategy & \\
\hline \multirow{9}{*}{ 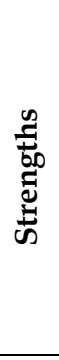 } & TOWS & TOWS & TOWS & TOWS & \\
\hline & NI: 13 & NI: 6 & NI: 8 & NI: 10 & \\
\hline & WNI: 3.8 & WNI: 1.7 & WNI: 2.6 & WNI: 2.7 & \\
\hline & TOWS/SWOT & TOWS/SWOT & TOWS/SWOT & TOWS/SWOT & \\
\hline & NI: 23 & NI: 25.2 & NI: 20 & NI: 24 & $\stackrel{0}{\mathscr{2}}$ \\
\hline & WNI: 6.3 & WNI: 6.7 & WNI: 6.2 & WNI: 6.2 & \\
\hline & SWOT & SWOT & SWOT & SWOT & \\
\hline & NI: 10 & NI: 19.2 & NI: 12 & NI: 14 & \\
\hline & WNI: 2.5 & WNI: 5.0 & WNI: 3.6 & WNI: 3.5 & \\
\hline \multirow{10}{*}{ 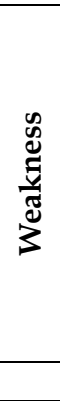 } & TOWS & TOWS & TOWS & TOWS & \\
\hline & NI: 14 & NI: 7 & NI: 2 & NI: 2 & \\
\hline & WNI: 3.9 & WNI: 2.4 & WNI: 0.5 & WNI: 0.9 & \\
\hline & TOWS/SWOT & TOWS/SWOT & TOWS/SWOT & TOWS/SWOT & $\sum_{0}^{2}$ \\
\hline & NI: 36 & NI: 25 & NI: 16 & NI: 14 & $\hat{\theta}$ \\
\hline & WNI: 10.2 & WNI: 7.8 & WNI: 4.9 & WNI: 5.0 & \\
\hline & SWOT & SWOT & SWOT & SWOT & \\
\hline & NI: 22 & NI: 18 & NI: 14 & NI: 12 & \\
\hline & WNI: 6.3 & WNI: 5.4 & WNI: 4.4 & WNI: 4.1 & \\
\hline & Competitive strategy & Defensive strategy & Competitive strategy & Defensive strategy & \\
\hline
\end{tabular}

where: NI - number of interactions; WNI - weighted number of interactions

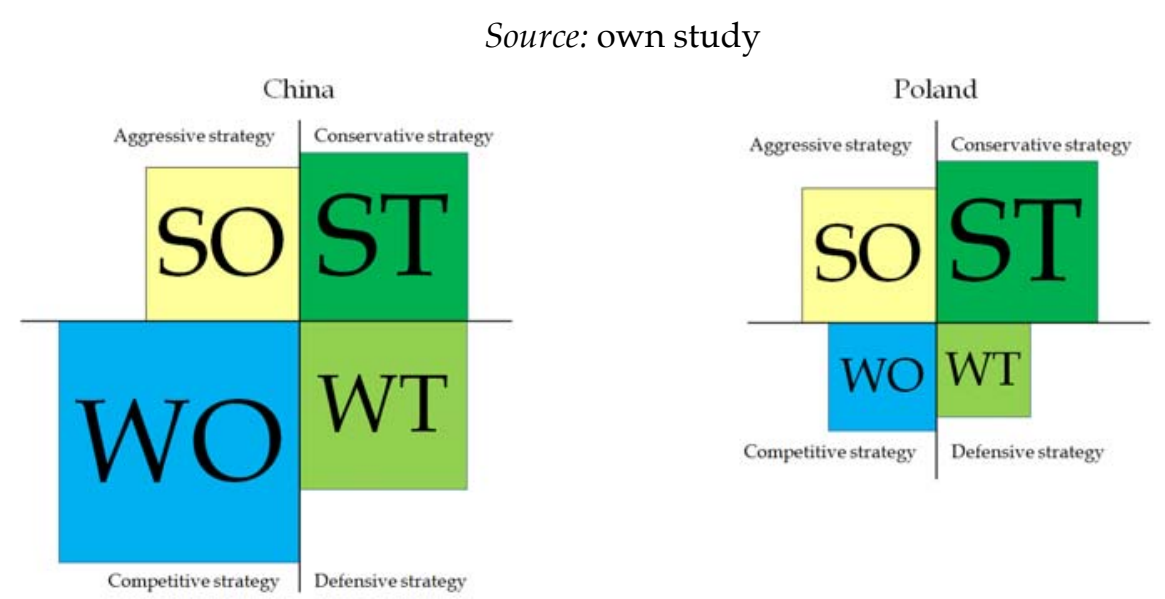

Fig. 8. TOWS/SWOT strategies for Chinese and Polish real estate management. Source: own study.

\section{Discussion and conclusions}

The situation in China is clear. There is only one possible strategy, i.e. a competitive one. The basic strengths are: S1 - effectiveness and S2 - the legal system. Investing in these two areas lets the Chinese management system exploit the most important opportunities: O1 - increase of market normalization and $\mathrm{O} 2$ - the reform of land expropriation. The proposed strategy maximizes opportunities. It also minimizes weaknesses (W1 - administrative intervention to real estate market and W2 - lack of legal transparency).

The Polish situation is less obvious in terms of defining the real estate management strategy. The conservative strategy obtained the highest score $(24 ; 6.2)$, but aggressive $(20 ; 6.2)$, competitive $(16 ; 4.9)$ and defensive $(14 ; 5.0)$ ones were characterized by scores not diverging much from that of the first. The conservative strategy maximizes such strengths as: S1-legal system and S3 - existence of the Integrated Real Estate Information System (ZSIN). Poland should invest in such opportunities as: $\mathrm{O} 1$ - completion of works on the ZSIN and O2 - implementation of more PPP projects. The 
conservative strategy minimizes threats appearing in the environment such as: $\mathrm{T} 1$ - growing debt of governments and T2 - legal limitations of sharing data form ZSIN.

As evidenced in Table 8, two different results of an analysis can be obtained. The outcome depends on what reference point is taken into consideration. When considering results of the TOWS analysis (from the outside inwards), the proposed order of development directions in China is as follows: the competitive, aggressive, defensive and conservative strategy. When considering results of the SWOT analysis (from the inside to the outside), the results for China are the following: competitive, conservative, defensive and aggressive strategy. A similar situation occurs in Poland. When considering results of circumstances analyzed from the outside inwards, the proposed order of development directions is the following: conservative, aggressive, defensive and competitive strategy. However, considering results of an analysis made from the inside to the outside, the sequence of the strategies is as follows: competitive, conservative, defensive and aggressive. This is why, in order to achieve equivalent results, a TOWS/SWOT analysis was used.

In accordance with the TOWS/SWOT analysis, both countries should make some changes in the real estate management systems. China lacks an integrated registration and information system concerning real estate, hence there is a need to create such a system. Poland now has the Integrated Real Estate Information System (ZSIN) past the second phase of its formation. China has to limit administrative interference with the real estate market and strengthen the role of market mechanisms. Poland should focus on making management more effective and on making management procedures simpler and less detailed (understandable for everybody).

The results achieved from our research justify the following conclusions:

1) A TOWS/SWOT analysis is a good tool for determining real estate management directions of development. It can also be used to determine strategic directions in other fields, such as in cadaster and land administration.

2) Strategic planning on the basis of a TOWS/SWOT analysis helps to identify the most desirable decisions in the scope of real estate management. The analysis should be repeated every time when features of the environment have changed.

3) The analyzed countries differ in regards to real estate management. The analysis described in this article is a preliminary step and a contribution to further research.

\section{References}

Bełej, M. (2001). Metodyka badania systemu katastralnego i formułowania strategicznych kierunków jego rozwoju (Research methodics of the cadastral system and formulating strategic directions of its development). PhD Thesis performed under the guidance of prof. dr hab. inż. Sabina Źróbek, Typescript, UWM, Olsztyn.

Bieda, A. \& Brzozowska, A. (2017). Analiza SWOT/TOWS jako metoda określania kierunków rozwoju przestrzennego (SWOT/TOWS analysis as a method of defining spatial development directions). Acta Scientiarum Polonorum. Administratio Locorum, 16(3).

Bieda, A., Wójciak, E. \& Parzych, P. (2018) Assessment of valuation methodology for land properties with mineral deposits used in Poland. Acta Montanistica Slovaca, 23(2), 184-193.

Bieniek, G. (2011). Gospodarka nieruchomościami (Real Estate Management) [In:] Bieniek G., Rudnicki S. Nieruchomości. Problematyka prawna (Real estate. Legal issues), Warsaw: LexisNexis, Edition 6.

Constantin, D.L., Dragusin, M., Petrescu, R.M. \& Iosif A.E., (2012). The effective management of municipal real property. The question of services for the business use of real property, Amfiteatru Economic, 14, Issue Special No. 6, 738-754.

Dawidowicz, A. \& Źrobek, R. (2011). Application of the strategic analysis method to assess the development possibility of the real estate cadastre in Poland. Proceedings of 3-rd Cadastral Congress, Warsaw, Poland, 283-296.

Dawidowicz, A. \& Źrobek, R. (2014). Multipurpose water-marine cadastre in Poland - development directions. Acta Adriatica, 55(2), 127- 144.

Godfrey, E.B. (2007). Public land management: Lessons from the past and implications for the future. Journal of Agricultural and Resource Economics, 32(3), 567-567.

Gross, M., \& Źróbek, R. (2015). Good governance in some public real estate management systems. Land Use Policy, 49, 352-364. https://doi.org/10.1016/j.landusepol.2015.08.017 
GUS. 2019. Bank Danych Lokalnych (Local Data Bank). https://bdl.stat.gov.pl/BDL/start, Available at 04.03.2019.

Kaganova, O., Akmatov, A. \& Undeland, C., (2008). Introducing more transparent and efficient land management in post-socialist cities: lessons from Kyrgyzstan. International Journal of Strategic Property Management, 12(3), 161-181, https:/ / doi.org/10.3846/1648-715X.2008.12.161-181.

Kokot, S. \& Gnat, S. (2010). Problem efektywności gospodarki nieruchomościami gmin, (The problem of the efficiency of the economy of communes' properties) Studia i Materiały Towarzystwa Naukowego Nieruchomości, 18(2), 29-44.

Lin, C. (2018). Tthe comparison and references of rural residential land institution between China and Vietnam [J] [in Chinese]. World Agriculture, 9, 107-113.

Lin, C. (2018). The institution change of urban and rural construction land from the perspective of a unified market: Based on a life cycle mode of incomplete property right [J] [in Chinese]. Zhongguo Nongcun Guancha, 2, 30-46.

Lin, C., \& Tan, J. (2013). The study on institutional reform of rural residential land based on perspective of function evolution [J] [in Chinese]. Economy System Reform, 5, 69-72.

Marona, B., \& van den Beemt-Tjeerdsma, A. (2018). Impact of public management approaches on municipal real estate management in Poland and the Netherlands. Sustainability, 10, 4291. https://doi.org/10.3390/su10114291

Nowacki, P. (2008). Efektywne gospodarowanie nieruchomościami w organizacjach gospodarczych $\mathrm{z}$ wykorzystaniem praktyk facility management (Efficient real estate management in commercial entities with the aid of facility management practices). Studia i Materiaty Towarzystwa Naukowego Nieruchomości, 16(1), 53-66.

Obłój, K. (2014) Strategia organizacji (Organization's strategy). PWE. ISBN 978-83-208-2165-9.

Pawlikowska, E., Popek, P., Bieda, A. \& Stoeva A. (2017). Analysis of the legal methods of agricultural land protection in central europe on the example of Poland and Bulgaria, Real Estate Management and Valuation, 25(2), 58-71. https:/ / doi.org/10.1515/remav-2017-0013, Available at 12.03.2019.

Polat, Z.A., Alkan, M. \& Sürmeneli H.G. (2017). Determining strategies for the cadastre 2034 vision using an AHP-Based SWOT analysis: A case study for the turkish cadastral and land administration system. Land Use Policy, 67, 151-166. https:/ / doi.org/10.1016/j.landusepol.2017.05.004

Požega, Ž., Crnković, B. \& Živković, A. (2014). Effective management of state property as prerequisites for economic development, Econ. East. Croat. Yesterday Today Tomorrow, 3, 418-426.

Struzik, A. \& Źróbek, R. (2010). Efektywność w gospodarowaniu publicznymi zasobami nieruchomości: metody oceny opłacalności publicznych projektów inwestycyjnych (Effectiveness of management of public resources of real estates: methods of evaluation cost effectiveness of public investment projects), Przeglad Geodezyjny, 2, 7-14.

The General Counsel to the Republic of Poland (Prezes Prokuratorii Generalnej Rzeczypospolitej Polskiej). (2018). Sprawozdanie o stanie mienia Skarbu Państwa według stanu na dzień 31 grudnia 2017 r. (Report about the status of the State Treasury assets as of 31 December 2017) http:/ / orka.sejm.gov.pl/Druki8ka.nsf/0/439856BF9658E27EC125832F00334A37/\%24File/2938.pd f. Available at 04.03.2019.

The National People's Congress of the People's Republic of China. (2019). Rural Land Contract Law [EB/OL], www.npc.gov.cn/npc/xinwen/2019-01/07/content_2070250.htm, Available at 11.03.2019.

The National People's Congress of the People's Republic of China. (2014). Real Estate Registration Ordinance [EB/OL], www.npc.gov.cn/npc/xinwen/lfgz/2014-12/23/content_1890386.htm. Available at 11.03.2019.

The National People's Congress of the People's Republic of China. (2004). Land Management Law (2004) [EB/OL], http://www.npc.gov.cn/huiyi/lfzt/tdglfxza/2012-12/19/content_1747507.htm. Available at 11.03.2019.

The State Council. (1998). Note on the further reform of urban housing system and acceleration of housing construction [EB/OL], http://www.bjjs.gov.cn/bjjs/fwgl/zfgg/zfgg/350118/index.shtml. Available at 11.03.2019.

The National People's Congress of the People's Republic of China. (2018). The Constitution of the People's Republic of China [EB/OL], http://www.npc.gov.cn/npc/xinwen/node_505.htm, Available at 11.03.2019. 
The National People's Congress of the People's Republic of China. (2007). Property Law [EB/OL]. http://www.npc.gov.cn/npc/lfzt/rlyw/2016-07/01/content_1992736.htm, Available at 11.03.2019

Ustawa z dnia 23 kwietnia 1964 r. Kodeks cywilny, tj.: Dz. U. z 2018 r. poz. 1025 ze zm., (Civil Code, 23 th April 1964, consolidated text: Journal of Laws, 2018, item 1025, as amended).

Ustawa z dnia 21 sierpnia 1997 r. o gospodarce nieruchomościami, tj.: Dz. U. z 2018 r. poz. 2204 ze zm. (Real Estate Management Act, 21 ${ }^{\text {st }}$ August 1997, consolidated text: Journal of Laws, 2018, item 2204, as amended).

Ustawa z dnia 21 czerwca 2001 r. o ochronie praw lokatorów, mieszkaniowym zasobie gminy i o zmianie Kodeksu cywilnego, tj.: Dz. U. 2019 poz. 1182 (Act of the protection of tenants' rights, municipal housing stock and the amendment of the Civil Code, 21 ${ }^{\text {st }}$ June 2001, consolidated text: Journal of Laws, 2019, item 1182).

Walacik M. 2014. Opracowanie zasad ustalania wysokości stusznego odszkodowania za nieruchomości przejęte na cele publiczne (Development of rules for determining the amount of just compensation for real estate taken over for public purposes), NDB, ISBN 978-83-929363-0-5, Olsztyn. http://www.ndb.pl/files/wydawnictwo/Seria_Nieruchomosci-Monografia_2014-1.pdf, Available at 12.03.2019 . 